\section{US Geological Survey needs more resources, says draft report}

\section{Rex Dalton, San Diego}

Research programmes at the US Geological Survey (USGS) should be buttressed with added funding, new staff and independent advisory committees, according to the draft of a report by the National Academy of Sciences (NAS).

The recommendations, a final version of which could be released as soon as this week, are intended to strengthen an agency that is widely seen as the US government's premier authority on Earth sciences.

The report warns that, unless personnel and financial issues are dealt with soon,

"the USGS may be unable to meet all of its mission goals, respond rapidly to new challenges and opportunities, and [become] the nation's Earth-resource science and information management agency".

Already more than a year overdue, the report is the work of a panel of experts brought together by the academy's National Research Council to examine a 120-year-old agency that has been buffeted by political and economic forces in recent years.

In the mid-1990s, Republicans in Congress tried to close the agency, which has about 10,000 employees and an annual budget of about $\$ 1.1$ billion, and is concerned with geology, water resources, mapping and biological resources.

The Republican bid grew out of conflict with President Bill Clinton's administration over environmental policy. As a compromise, the agency's staff was cut and a contract reached with the NAS to help chart a course for the future.

The draft report points out that, although the agency has recently built "a solid foundation on which to plan its future", a number of improvements are still needed to meet its long-term goals.

To ensure rigorous review of research projects, for example, it recommends that the agency "establish and make extensive use of external advisory committees" at national and regional levels. Such a move would be welcomed both inside and outside the USGS, as it would be seen as improving the scientific quality of its research.

The report also calls for greater emphasis on "multiscale, multidisciplinary projects" that integrate Earth and environmental problems. And it says that, to become more of "an information management" agency, the USGS "should shift from a more passive role of study and analysis to one that seeks actively to convey information in ways that are responsive to the social, political and economic needs".

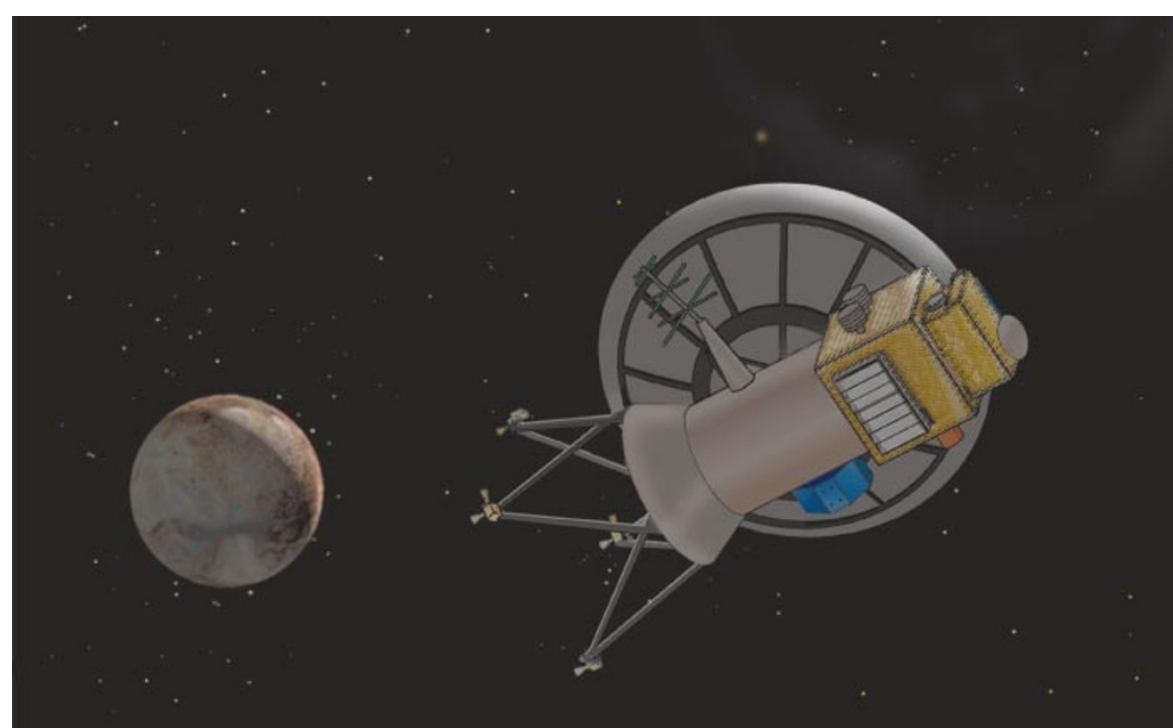

Not so fast: on its new schedule, a revised Pluto-Kuiper Express will not reach Pluto until 2020.

\title{
Fan mail demands reprieve for delayed US Pluto mission
}

\section{William Triplett, Washington}

If you think Americans don't pay much attention to the least-explored planet in the Solar System, think again. Supporters of the US space agency NASA's Pluto-Kuiper Express mission - postponed last month for financial reasons - are letting their congressmen know about their unhappiness.

Last week, Louis Friedman, executive director of the Planetary Society in Pasadena, California, an organization of spaceexploration enthusiasts, and television personality Bill Nye, a member of its board of directors, visited Washington to deliver 10,000 postcards and letters that the group has received from members who want the mission reinstated without delay.

Nye went to the office of Dana Rohrabacher (Republican, California), chairman of the space and aeronautics subcommittee of the House of Representatives science committee, to deliver 5,000 of the missives. Friedman took the other 5,000 to the office of Bill Frist (Republican, Tennessee), chair of the Senate science, technology and space subcommittee.

The key issue is timing. The Pluto-Kuiper Express, a space probe intended to take readings of Pluto's fragile atmosphere, was originally scheduled to be launched in 2004 and to arrive in 2012. On the new schedule, announced in September, the spacecraft will not reach Pluto until 2020.

Some scientists say this will be too late to provide the data they are hoping to collect. The further the planet travels from the Sun, the colder it gets - by 2020, Pluto's atmosphere may have frozen, and it would be about 200 years before it thaws again.

Another problem with the delay is that, at $\approx \odot 2000$ Macmillan Magazines Ltd the original launch date, the planet Jupiter would have given a valuable gravity assist, giving the spacecraft a slingshot-like push as it flew by. There will be no such assist under the new schedule.

NASA's decision to postpone the launch - taken shortly after the agency announced it was planning more extensive, and expensive, surface exploration of Mars - immediately freed up the $\$ 500$ million that the Mars project was expected to cost.

But Nye is said to have told Rohrabacher that NASA had not been totally open about the reasons for the delay. According to Susan Lendroth, events and communications manager for the Planetary Society, Rohrabacher told Nye that he "would look into it".

Ricardo Bernal, a member of Rohrabacher's staff, says the congressman plans to talk to NASA officials in January, when the new Congress convenes. "He wants to look into it very carefully to find out exactly why the mission was put on hold," says Bernal.

If the reasons turn out to be purely financial, Rohrabacher will want to know "exactly how much more will be needed", says Bernal. "He'll also want to know if there might be other options, such as a smaller probe."

Ed Weiler, NASA's associate administrator for space science, says the decision was "absolutely based on budgetary concerns". Referring to Nye's meeting with Rohrabacher, Weiler says he thinks the Planetary Society "did a great job of showing support for the Pluto mission, but they were literally a day late and a dollar short". NASA's appropriations bill for the fiscal year 2001 was passed by the house an hour after the meeting.

inttp://planetary.org 